\title{
ラスキンとヴイオレ＝ル＝デュク
}

\author{
19 世紀アメリカにおける機能主義理論の系譜
}

\section{RUSKIN AND VIOLLET-LE-DUC}

The genealogy of functionalist architectural theory in mid-19th century America

\section{江 本 弘*}

\section{Hiroshi EMOTO}

\begin{abstract}
The American reception of the two eminent architectural theoreticians, namely the Englishman John Ruskin and Frenchman Eugène Emmanuel Viollet-le-Duc, was preceded by the formulation of functionalist theory before 1850 by Horatio Greenough, whose idea of architectural design would be widely popularized by Ralph Waldo Emerson, the leading philosopher of transcendentalism, just after Greenough's untimely death. This introductory phase led to the portrayal of Ruskin as a functionalist; Viollet-le-Duc would eventually take his place during the Francophile tide of the 60's. Thus, the American architectural world elaborated its own consistent functionalist genealogy, while referring and freely interpreting the words of these men according to contemporary thought, before the translated publication of Discourses on Architecture in 1875.
\end{abstract}

Keywords : American architecture, reception history, H. G reenough, J. Ruskin, E. E. Viollet-le-Duc, functionalist theory アメリカ建築，受容史，H・グリーノウ，J・ラスキン， $\mathrm{E} ・ \mathrm{E} ・$ ヴィオレ $=$ ルニデュク，機能主義理論

\section{1. はじめに}

エコール・デ・ボザール卒業生を輩出するようになった 1850 年 代半ば以降, アメリカ建築界は, 主にイギリスの美学・建築理論に 依拠したそれまでの潮流から, 次第にフランス建築界の動向に関す る知識を得るようになり, 後者との共同歩調も模索しはじめた。イ ギリスのジョン・ラスキン〔1819-1900〕，フランスのウジェーヌ・ エマニュエル・ヴィオレ $=$ ル $=$ デュク 〔1814-1879〕という 2 人の 建築理論家は, この過程のなかでの主要な参照点となった。

一方，アメリカ人彫刻家のホレーシオ・グリーノウ〔1805-1852〕 は,このラスキン受容とヴィオレ $=$ ウ =デュク受容に先駆けた 1840 年代初頭から建築理論を起草していた。それらは「機”能䍿義」と いう術語が使われるようになる遥か以前に明言された機能主義理論 として，20世紀中葉には「進歩的な同時代人の言葉のようだ」1)と 評されることとなるものだった，しかし彼らは，グリーノウは「不 可解な奇才」 $(\mathrm{N} \cdot$ ペヴズナー) 2$)$ であり、同時代的には「無視され た」(R・スタイン）3ののだとして，19 世紀中葉前後のアメリカ建築 論壇の展開から孤立したものと見做した.

しかしアメリカを対象としたラスキン受容史研究の蓄積は, グリ 一ノウの活動とその後の論壇の展開との連続性を示唆している ${ }^{4)}$. なかでもスタインによる研究は, 1840 年代末からラスキンの美論が 爆発的に受け入れられた要因に, 「エマーソンやその他少数に訴えか けた」グリーノウの建築美論と, ラスキンのそれとの部分的相似性 を指摘した。
同国のヴィオレ=ル＝デュク受容に関する先行研究はラスキンほ ど充実しておらず，また，そのほとんどがラスキン受容史研究に付 随して進められた 5 . それは 19 世紀後半, 特に 70 年代までのアメ リカの建築界において, ラスキンの知名度および言及頻度が他に類

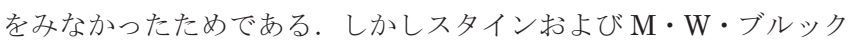
スが指摘する通り, 1870 年前後には, それまで主流を占めた「ラス

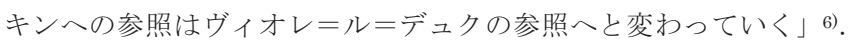

グリーノウ，ラスキン， ヴィオレ＝ル＝デュクという 3 人の建築 理論家が受容される過程には, このように 2 つの遷移期の存在が指 摘される.しかし，それらがいかなる要因のもとに起こったかとい うことについては, 各々の時代相から別個の要因が示されるにとど まり,その全体を連続的・一体的にとらえる試みはなされていない.

そこで本論は, 19 世紀中葉以降の三者の受容を複合的に再踏査し, その受容様態にみられるアメリカの建築思潮の変遷を明らかにする。 ここでは新たに, 19 世紀アメリカの書籍・雑誌からこの三者に言及 した史料に対する悉皆調查が行われ，それらの成立背景および相互 関係が分析されている．ただし本論文の紙幅では膨大な史料の全数 を挙げることは叶わず, 主要論考とその補足資料を示すにとどまる.

\section{1840 年代末〜1850 年代 : 初期ラスキン受容}

\section{1. 超越論の伝統とアメリカのラスキン受容}

ヴィオレ =ル =デュク受容に先だつ 1840 年代末から 50 年代, ラ スキンの文筆は，本国イギリスよりもアメリカにおいて好意的に評

* 東京大学大学院工学系研究科建築学専攻 博士後期課程 · 工修 
価された. 1847 年に『モダン・ペインターズ』アメリカ版 7)が出版 された時点から, 文芸批評誌は長編の批評記事を掲載し, 1849 年に 出版された『建築の七燈』は即座に粗製の海賊版としてアメリカ国 内に流通，主要文芸誌はこぞって同書を批評・紹介した ${ }^{8)}$.

この現象は一面において, 当時のアメリカ知識人たちが広く意識 していた国内の文化的後進性から, 彼らがイギリスの文物を積極的 に取り入れていたことの反映である.しかし，このとき特にラスキ ンの芸術論・自然哲学が受け入れられた背景には, 当時のアメリカ の思想界が $\mathrm{R} ・ \mathrm{~W} ・$ エマーソン〔1803-1882〕の超越論によって牵 引されていたという事情があった。

エマーソンの自然観は 1836 年の『自然』9)にはじめて明言された. ここでは「宍踫」という汎神論的概念が提示され，この超越的な 力によって人間を含むすべての自然（宇宙）が秩序づけられている ことが論じられた。この力は, 人間の感性と知性が無限に拡大され ることによって感じられ，理解される．

この造物主論は『モダン・ペインターズ』に提示された自然観・ 芸術観と親和性がよかった。 そのため 40 年代末以降のアメリカで は，同書はこの超越論的世界観の芸術理論への応用であると理解さ れた。そうして，この『モダン・ペインターズ』受容を経たのちの 『建築の七燈』もまた，この超越論の文脈で受容される. A ・ J ・ ダ ウニング〔1815-1852〕の『カントリーハウス建築』（1850）10)は, 「人間の精神的, 心的, 知的性質の象徵となる物質は寸べて, 人間 のなかの美なるものを示唆するために, 同時に美にもなり得る」と 定義し, 彼が既に提唱していた「建築の真実性」の問題を, 『建築の 七燈』の美論を援用し語った建築書である. そして彼は, 建築家に よる創作の霊感源を, 超越論的に理解された自然にもとめた ${ }^{11)}$.

\section{2. グリーノウの機能主義美学}

以降, 50 年代のアメリカ建築論壇において, ラスキンの美術思想 に対する理解に影響があったのは，エマーソン自身によるグリーノ ウの建築理論の紹介である.グリーノウ自身は明確にラスキンのこ とが「嫌い」12)であり超越論のグループとも距離を置いたが，エマ ーソンを介して, 50 年代のアメリカではラスキンはグリーノウの系 譜に位置づけられるようになる。

グリーノウの機能主義美学を最もよく要約しているのは, 美を「機 能の裏付け」と定義した「美の探求」の冒頭部である。この思想は 「構造と編成」や「相対美と独立美」のなかでも展開され 13), 友人 エマーソンに宛てた書簡のなかでは,

機能と敷地に合わせて，空間と造形を科学的に配置する．造作 は，それが機能のなかで有する段階的な重要度に合わせて強調 寸る，色彩と装飾は，厳密に有機的な規則によって，各決定に 明確な理由を持たせて決め，配置し，変化させる，間に合わせ や見せ掛けはすべて，即座に完全に追放する。14)

と語られた. グリーノウの文筆で 19 世紀に最も参照されたのは, この書簡および, 1843 年が初出の「アメリカ建築」である ${ }^{15)}$. こ れは「新たな建築様式を作るのはこの合衆国だ」という標語に基づ き, 生物の適応法則を範とした建築表現の進歩を提唱した建築論で ある.グリーノウによれば「適応法則はすべての構造体における基
本的な自然法則」なのであり，工業においてその適応法則を反映す る「造船に求められる責任を普通建築にも導入する」ことがアメリ 力喫緊の課題だった。

ただしグリーノウの理論は生前に読者を得ること叶わず，それが 19 世紀アメリカの建築論壇で参照されていたのは 1852 年の没から 60 年代半ばまでの 10 年程度のことである. その後 1930 年代後半 から再評価されるまでの約三四半世紀のあいだ，彼の名がアメリカ の建築論壇に現れることはなかった ${ }^{16) .}$

\section{3. エマーソンとグリーノウ=ラスキン}

しかしグリーノウの機能主義美学は実際は「無視された」(スタイ ン）のではなく，エマーソンによる解釈を通じて「ラスキンの建築 論」と同一のものとして伝えられた。もともとエマーソンは「七燈』 と『石』を読んでいた」17)が，彼がそれらとグリーノウの理論に相 同性を見いだしたのは, グリーノウ没直前の 1851 年のことである. このときエマーソンはグリーノウに宛て，ラスキンが「あれだけの エネルギーを注いで呼びかけたものを君〔グリーノウ〕は既に説き 続けていた」18)のだと語った

グリーノウの没にあたっては追悼論集も発表されたが，同時代的 な再評価の直接の引き金となったのはエマーソンによる『イギリス の特質』（1856）の出版である ${ }^{19)}$ 。ここで彼は，自分宛のグリー， ウの書簡（上掲引用）を参照することでグリーノウとラスキンの建 築観をともに機能主義的なものとみなし，前者の建築論を「建築の 精神性にまつわるラスキン氏の思想に先んじたもの」と位置づけた. 1857 年のコスモポリタン・アート・アソシエーション講演でも, エ マーソンは「美は自然の隅々にわたって構造の優位を示唆する」,「真 なるもののみが美しい」という主張について,「ケスラー, ラスキン, グリーノウらの文筆家の教えは皆一致する」とした ${ }^{20)}$.

エマーソンによるこうした言及は，50 年代のアメリカにおいて， 機能主義者として，また超越論者としてのラスキンとグリーノウの イメージ形成に寄与し，50 年代末には, グリーノウの建築論はラス キンの建築論に準ずるものとして,「先だついかなる定義よりも我々 の時代に建築が意味寸るものに近い」ものと見做されるようになっ た ${ }^{21)}$. 当時急先鋒としてラスキンの美論に依拠していた L・アイド リッツ〔1823-1908〕は『イギリスの特質』出版から 2 年後に「様 式論」を発表したが，これは「芸術の母である自然は建築家が行う 統御のための唯一の指導原理」であると定めた点，生物にみられる 合理的な配置解決を建築に応用すべきであると主張した点, 船舶の 科学的発展を建築になぞらえた点において, 40 年代末以降アメリカ の主流を形成してきた超越論的二機能主義的建築観が, 初めて国内 の建築家から明言されたものである ${ }^{22) .}$

\section{1850 年代末 : ヴィオレ=ル=デュク受容まで \\ 3. 1 .「フランス派」の形成}

ヴィオレ =ル =デュクの理論がアメリカの建築界で支持されるよ うになるのは『建築講話』23)出版以降の 60 年代半ばのことである. 50 年代においても彼は『中世建築事典』の著者として紹介されてい たが, 彼の理論は, 60 年代初頭まではアメリカの論壇に直接かかわ るものとは見做されていなかった ${ }^{24)}$.

しかし 50 年代は， 60 年代のヴィオレ $=$ ル =デュク受容の前提と 
して, R・M・ハント〔1827-1895〕を中心とした，アメリカ建築界 における「フランス派」25)の形成をみている。 ハントはアメリカ人 初のボザール卒業生として AIA (American Institute of Architects) の設立に携わった一方, アメリカ初のスタジオ・システムの設計事 務所を運営し, のちに『建築講話』の訳者となる $\mathrm{H} ・$ ヴァン・ブラ ント〔1832-1903〕 26)をはじめとして, W・R・ウェア〔1832-1915]， $\mathrm{F} ・ \mathrm{H} ・$ ファーネス〔1839-1912〕などの建築家を擁した.

1860 年代以降のアメリカでは, 理論・実践ともにゴシック・リバ イバルの動向が目立っていた. しかしその後, 国内でフランス文化 への傾倒が強まると, ボザールが理想とする古典主義（フレンチ・ ルネサンス）に関心が集まる。ハントを嗃矢とする「フランス派」 はこの潮流の源流にあたり, ときのゴシック・リバイバルの潮流の なかで現代的な建築理論と建築表現を模索した. 彼らは必ずしも古 典主義建築の実践者ではなかったが,「ゴシック党とクラシック党の あいだで広く行われていた論争」27)の後者陣営であることを自認し, ゴシックの超克を目論んだ.

\section{2. 鋳鉄装飾論争におけるラスキン}

ただし 50 年代には, ハント門下とその他の陣営には明確な派閥 関係は生まれていなかった。当時フランス派の建築家たちには援用 すべきフランス人の理論家が存在せず,「ラスキンが芸術における善 であり真であるものすべての提唱者」28)であるほかなかった．

この状況に変化が現れたのは, 1858 年末に行われた鋳鉄装飾論争 の時点である ${ }^{29}$. これは八ント門下の若手建築家ヴァン・ブラント と, 当時すでに中堅となっていたアイドリッツが鉄構造一般の建築 への応用をめぐって行った論争である. ここで, それまで金科玉条 として奉じられた「ラスキンの建築論」に対する疑念が初めて顕在 化した. 当時アメリカの建築論壇では, 建築への鋳鉄の応用は一般 に支持されていた.『建築の七燈』中で鋳鉄を忌避したラスキンの建 築論は, 論壇の見解との不和を見せはじめていた.

ヴァン・ブラントは「唯一の純粋な泉一構造的必然一から直接に 発生」する建築設計を至上とし，黎明期にある鉄造建築の可能性を 高く評価した。「鉄は安く, 早く簡単に施工でき, すばやくどのよう な形にもなる.現在の社会の状態のなかでは, 鉄のこれらの性質は, ラスキンが断じるような,『寸でに障害物の多い道の上にあらわれた, 非常に多くの新たな障害物』ではない。この金属は, そのためにこ そ大衆建築の財として特に貴重なのである」.これに対しアイドリッ ツは,「すでに確固たる地位を築いた」,「もっとも大胆で, もっとも ひたむきで, もっとも熱心な芸術唱道者ラスキン」擁護の立場をと り，『建築の七燈』に語られる鋳鉄不使用のドグマに固執した.

しかし，このようにラスキンのドグマを支持したアイドリッツで さえ, 国内建築分野の技術革新には肯定的だった. 彼は一見鋳鉄反 対派の立場をとりながら, 「時代遅れの偏見にばかり取りつかれてい るのではないことを示すためになら, 鉄の梁, 鉄の屋根, 鉄のサッ シュの, 上質の石造家屋を作ってやってもいい」とさえ語った. ま た彼は, この論争に先だつ 1852 年, ニューヨーク万国博覧会のコ ンペティションに鋳鉄とガラスのパヴィリオンを提案していた ${ }^{30)}$.

\section{3. ジェネラリストからゴシック主義者へ}

こうして 50 年代末にはラスキンの教条に対する疑念が顕在化し
た.しかしこの頃には, ラスキンはまだ建築の一般的原理の唱道者 （=ジェネラリスト）として理解される場合が多く, 彼のことをゴ シック論者とのみ見る論者は少なかった ${ }^{31)}$.

いわゆるラスキニアン・ゴシックには 50 年代にもオール・ソウ ルズ・ユニタリアン教会 $(\mathrm{J} \cdot \mathrm{W} \cdot$ モールド設計, 1853) などの作 例があったが，アメリカにおいてラスキンに依拠したゴシック・リ バイバルの本格化は 60 年代前半からである. この時点から, ラス キンはゴシック論者としてのイメージが根づく.その影響源は, C・ クック〔1828-1900〕を中心とした SATA ( Society for the Advancement of Truth in Art）である. その設立メンバーには建築 家・建築批評家として P・B・ワイト〔1838-1925〕と R・スタージ ス〔1836-1909〕がおり, 機関誌『ザ・ニュー・パス』(1863-65) のなかでは, 自然の造形原理の観察・応用を基礎とする「所謂『ゴ シック芸術』の回復」が掲げられた ${ }^{32)}$. この運動はイギリスのラフ アエル前派の活動と連動したものであり, 彼ら同士の情報交流のな かで，ラスキンの建築理念・社会理念は中世主義と同一のものと見 做されるようになった。

SATA の建築家は, ナショナル・アカデミー・オブ・デザイン (ワ イト，1863-65）やファーマン・ホール（スタージス, 1869）など を設計し，アメリカにおけるゴシック・リバイバルの潮流を継承し た. 以後国内のゴシック建築の流行は 70 年代まで続き,『建築講話』 が訳出出版された 1875 年には「ゴシック・リバイバルはすでに人 気と流行の絶頂に達していた」33).

\section{1860 年代 : ラスキンからヴィオレ＝ル＝デュクへ}

\section{1. 初期ヴィオレ=ルニデュク受容}

しかし, 建築表現におけるゴシック・リバイバルの流行の裏では, 合理的建築一般の理論を求める議論は継続していた，そのようなな かで、『建築講話』を中心としたヴィオレ=ル＝デュクの理論は，ラ スキンの建築理論に対する疑念が顕在化したのちの 60 年代半ばか ら受容されたことにより，それまでのラスキンの理論に代わるもの として, 建築の合理性をめぐる国内の議論へと接続された.

また，ヴィオレ＝ル＝デュクの理論が『建築講話』の出版から間 もなくアメリカの建築論壇と密接な関係をもつものと理解されるよ うになったのは, ヴィオレ＝ル＝デュクのボザール講師就任

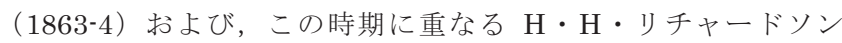
〔1838-1886〕のパリ留学にも原因がある。この就任は当時フラン ス本国で物議を醸し, 学生のあいだでボイコットが起こった。当時 ボザールの建築学生だったリチャードソンは, 先鋒としてこの教師 の拉致を目論み逮捕・拘留された ${ }^{34)}$.このリチャードソンの暴挙に よって「ヴィオレ=ル＝デュクの声は殺されたが，彼が建築芸術に 関する今世紀最大の重要著作である『建築講話』を公刊したのはそ の結果」35)というような風説の存在は, フランスの動向に対するア メリカの能動的干渉を後者側から強調するものとして, 60 年代アメ リカにおけりヴィオレ＝ル＝デュク受容の積極性を表している.

\section{2. ヴァン・ブラント「建築の改革」}

前節で述べた通り, 1860 年代の初期ヴィオレ =ル =デュク受容の 主要動機は, それまで覇権を有していたラスキンの建築理論への疑 念と, それに代わる理論的支柱の模索である. このため, 1860 年代 
以降にアメリカで発表されたヴィオレ＝ル＝デュク関連の論考は, ほとんどの場合がラスキンとの比較言及によって展開する。このな かで, 50 年代にはラスキンを援用して議論された機能主義建築理論 は，その援用元を徐々にヴィオレ＝ル＝デュクに乗りかえていく.

1866 年にヴァン・ブラントによって書かれた「建築の改革」は前 年に海賊版が出版された『建築講話』の書評だが，アメリカ建築界 の初期ヴィオレ =ル＝デュク受容の実態を示す重要論考としてこの 点を明確に示している ${ }^{36)}$. ヴァン・ブラントはその論内において, 古典主義陣営とゴシック主義陣営が「近代建築における新たなバベ ルの塔」を形成している建築界の現状を摘要しながら，その状況を 打破するべき「建築の大原理」の必要性を訴えた。 その標語とされ たのは「建築の真実」であり, ラスキンおよびヴィオレ＝ル＝デュ クは, この原理を求めた主要な理論家であるとされた.「ラスキンと その後続, そしてこの国の人間もまた, 彼らを代表とする論題に興 味をもちはじめた。芸術の実践に関して言えば，彼らの教義から帰 結した根本的なことは, 表現の真実の概念を導入してデザインする ようになったということである」. ヴァン・ブラントがヴィオレ＝ル =デュクの理論と人格を評価する直接の要因にも, ヴィオレ $=$ ウ = デュクが有するとされる「真実に対する敬意」があった．

\section{3. ジェネラリストとしてのヴィオレ＝ル＝デュク}

ここで特筆されるのは，当時のヴァン・ブラントの論において， ラスキンとヴィオレ＝ル＝デュクの両者がともにゴシック主義者と は見做されていないことである。論内において，ラスキンは「歴史 的先例をどのように用いればよいかという問題全体に対する慎重で 科学的な調查を始めよう, 論争のややこしい点を全て解決しよう という意図をもち, 新しい, 健全な進歩が始まりうる建築理論に辿 りつこう, 模做でも集塊でもない, 論理的な演繹としての, 我々の 時代に固有の様式に辿りつこう」とした人物であると描かれている. ヴィオレニル＝デュクもまた,「す心゙ての大時代を徹底的に, 綿密に, 鑑賞眼をもって調查することにより，建築の大原理を開発しようと した」人物であるとされる．

ヴァン・ブラントは脱党派的かつ合理的な「建築の大原理」の援 用元としてヴィオレ=ル＝デュクの理論を国内に紹介した．このよ うにヴィオレ＝ル＝デュクをジェネラリストとみる理解は, 「ゴシッ ク芸術の回復」を目指した SATAの建築家も含めて, アメリカの建 築界に早くから行きわたった。 ワイトは 1870 年, ヴィオレ $=$ ウ = デュクのことを「ゴシックの復興と理性的建築を唱える存命の人間 のなかで最も優れた人物である」と紹介しながらも，「彼の敵〔古典 主義者〕が思うよりも寛大である」ということを示すために，あえ て彼の古典主義建築論を訳出した ${ }^{37)}$.

\section{1860 年代末以降 : ヴィオレ=ル＝デュクの現代性}

\section{1. ラスキン忌避の潮流}

1860 年代アメリカの建築論壇にジェネラリストとしてのヴィオ レ=ル＝デュク像が根づいていく一方で，ラスキンはドグマチック なゴシック主義者として否定的に解釈されるようになる．この傾向 は 60 年代半ばに既にみられたが, 1867 年 4 月のパリ万国博覧会の 開場直後からは，それが明らかな否定の論調を帯びるようになる.

このとき,『ザ・ネイション』誌に「無価值以下の教科書」と題す
る記事が掲載された ${ }^{38)}$ ．これは当時新刊の『美術批評原論』39)に対 する書評である，同書は，「我々は，健全で修養された精神状態にあ るとき, 本能的に, 必然的に，[]とその〔神の〕性質の実例となる 事物から快を得るように作られている」とするラスキンの感性的批 評原理を基礎とし，実作批評においてもラスキンによる言及が多く 援用されたものである。そこで評者が特に問題としたのは，同書の 建築批評原理が特に『建築の七燈』の内容を中核に据えていたこと である.この点について評者は，「建築という多面的な芸術について 書かれた著作には, ヴィオレ =ルニデュクの『建築講話』という今 世紀最大の立派な労作がある」と論難した。この評者には，「急速な 成功を収めているラスキンの著作は皆，イギリスとアメリカに最近 生まれた, 新しい本来の批評に無くてはならないものである」とい う著者の見解は許容できるものではなかった ${ }^{40)}$.

このラスキン忌避の潮流は, 1850, 60 年代アメリカの知的文化, 特に感性批評や理知性の欠如に対寸る反省として，かつてラスキン の芸術理念を奉じた人物にさえ共有されたものだった. 50 年代には 熱烈なラスキン信奉者であったスティルマンも, 60 年代末には辛辣 なラスキン否定論者となった。彼は 1868 年の『ザ・ネイション』 誌に「ラスキンとその文筆」と題する論考を寄稿し，「芸術に関する ラスキンの教義はひどく誤っている」と断じた ${ }^{41)}$. 彼はその後もラ スキンに対するネガティブ・キャンペーンの先鋒となった ${ }^{42)}$.

\section{2. クック「コーナーストーン」にみるフランコフィル}

一方,「コーナーストーン」（1868） と題するクックの記事は, そ れまでのアメリカ建築思想を総括し，より合理的な建築理論を，そ れまでのラスキンではなく, 新たにヴィオレ=ル＝デュクに求めよ うとする明快な意思表示である ${ }^{43)}$. ダウニングの門弟であったクッ クは, 40 年代後半のアメリカの知的文化に浴した一人として, ステ イルマン同様，ラスキンの文筆に鼓舞された批評家である。そうし て彼は, SATAメンバーの最年長としてこの団体を主導していた.

しかし 60 年代末のクックは, 公衆を教化したダウニングの功績 を認めながらも，「善であり真であるものの側に，しっかり，はっき りと比重を置かなかった」彼の「負の影響」を強調した。クックに よれば，ダウニングから始まり 60 年代末まで続いたアメリカ建築 界の潮流は,「個人の意識がラスキンによって強く刺激された」イギ リス派の建築家たちが主流のものだった。しかし今，クックは「真 のフランス，知性と進歩，そして熱狂の国フランスに心を寄せ，建 設の真の原理を学ぼうではないか」と語り，過去のイギリスからの 影響の払拭に努めた

そこで唯一の拠り所とされたのが， ヴィオレ=ル＝デュクの理論 である.クックによれば,「ヴィオレ＝ル＝デュク氏の卓越した点と は，その教義の実践性であり，気まぐれや流行ではなく，原理に基 礎づけられているという点であり，形式的でも退廃的でもなく，熱 狂的で創造的」な点だった，実践に偏重したダウニングと空理に拘 泥したラスキンは，ともに乗り越えられるべき対象となっていた.

\section{3. 古典主義者ヴィオレ＝ル＝デュク}

以上の経緯のなかで, ヴィオレ＝ル＝デュクには「寛大な」（ワイ 卜）人物として, 様式的表現に拘らない, 合理的な「建築の大原理」 を唱導した理論家のイメージが形成された。しかし，さらにアメリ 
カの地では, 60 年代以降のボザール教育に対する需要の拡大と並行 して, かつてボザールの職を逐われたヴィオレ=ル＝デュクの理論 はむしろ, ボザールの権威主義および, その表現としての古典主義 建築の支持のために援用されることがあった ${ }^{44)}$.

その好例が, ヴァン・ブラントが行った『建築講話』の翻訳出版 （1875）である。その訳者序において彼はまず，同書を「フランス の土壌において, 古典様式が中世様式の地位を奪った歴史状況」の 史論であると断じた。それは 400 年の風雪に耐えたフレンチ・ルネ サンス様式の完成の歴史であり,「新しい国土を占領し, 廃䲣の遺産 もなく, 建築に関して伝統という邪魔もない」アメリカ人建築家の 模範として,「古代ギリシア人のような, 完璧を目指寸芸術家の配慮 と忍耐」の過程を示していた. ヴァン・ブラントにとっては, ボザ ール教育とその長期の歴史は，この忍耐を代表するものだった。

この言及の背景には, 当時のアメリカ建築界を席巻していたゴシ ック・リバイバルの一過性と, その表現の無秩序に対する反省があ った. 彼の整理によれば，1840 年代末に「ラスキンが芸術問題に関 する独裁者として文人の先例を立てて以降, 我々は美学分野におけ る恐ろしい独裁にさらされ」,「北イタリアの中世歴史建造物の色に 染められ」てきた。 そこでヴァン・ブラントは, この独裁からの解 放を目論み, 「現代文明の魂」であり,「みずからの時代の無意識的 表現」としての古典への回帰（ルネサンス）を目指したのである. 『建築講話』の翻訳出版はそのための方便としての性質を有してい たため, 訳者序のなかでヴィオレ＝ル＝デュクの中世主義者として の側面に触れられることは皆無であり, 『建築事典』編纂の功績も, 「自らの芸術理論の真の実践的発展のためではなく, フランス国内 におけるゴシック建築の史跡保存のため」と極端に矮小化された.

\section{4. スタージス「近代建築」と超越論的機能主義}

『建築講話』の翻訳出版までに, ヴィオレ＝ル＝デュクには純理 性的な建築理念を唱導した人物としてのイメージが根づいていた. それと並行した現象として, ラスキンには不合理な人物としての理 解が主流を占めるようになる.

しかし，ラスキンの建築理論を機能主義的美学のもとに理解する 50 年代以来の系譜は, その後もアメリカ建築論壇の中に存続してい た，そのことを示しているのが，スタージスが 1871 年に発表した 「現代建築」である ${ }^{45)}$. この論考は, 無装飾の純機能主義建築を奉 じた,アメリカ人建築家による初のマニフェストとして特筆される.

スタージスは当時ヴィオレ＝ル＝デュクを中世主義者と理解した 数少ない建築家である ${ }^{46)}$. その彼が奉じる機能主義の源流は中世に あり, ヴィオレ =ル＝デュクの引用によって, 中世人は「虚飾を知 っており，すべての物品は精確に目的に応えていた」と語られた。

そこで話題は現代に移り, 鋳鉄をはじめとする, 工業部材の表現 の妥当性が検討される。スタージスによれば，それらは石材とは異 なる製造法でありながら, 施される装飾は依然として石材の引き写 しであり，現代には鋳鉄に相応しい造形を「自分自身で考える」努 力が欠如している. 彼の論に従えば，機械によって製作される工業 部材はそれ自体が機能の表現であり, 未来の建築にはそれを直接表 示することこそが求められる。すなわち「装飾にはおそらく未来は ない」のであり，スタージスの見立てによれば，「これからは正しく 無装飾に建てられた建物が不快に映ることはなくなる」.そこでスタ
ージスが建築の模範としたのは船舶だった。

船とは本来, 我々が有する, 厳密に実利的なもののなかでも最 も完璧な種類のものである. すべての線は, 幾世代もの造船者 たちによって, 速度, 収容人数, 堪航性をもとめ幾世紀も繰り かえされた，入念な実験の結果なのだ。「ボートの船首は」， とラスキンは言う。「神の作品〔自然／宇宙〕に次いで，私の 知る最も美しいものだ。」47)

ここでスタージスはラスキンを引用しているが，これは彼の創作 であり，実際のラスキンの文筆にはない，しかし特筆されるのは， この引用によって, 40 年代末以降にラスキンと結びっけられていた, グリーノウ，エマーソン以降の機能主義的=超越論的な建築観が, 再びラスキンに対する言及を通じて明言されていることである。そ れは過去 20 年間, ラスキンとヴィオレ =ル =デュクに対する相互 参照により存続した「アメリカ的」建築観の摘要として，60 年代以 降ヴィオレ=ル＝デュクの理論の中に理解されるようになったもの とも無矛盾だった.

\section{6. 結語}

アメリカ建築論壇における機能主義美学の展開はグリーノウによ る 40 年代および 50 年代初頭の定式化を開始点にもつが，彼ひとり から発された論点ははじめ衆目を集めることはなかった。しかしそ れは,グリーノウ没後のエマーソンによる紹介を大きな契機として, まずイギリスのラスキン，次にフランスのヴィオレ＝ル＝デュクと いう 2 人の理論家に意識的・無意識的に付託され語られながら，ひ とつの論題としてアメリカの建築論壇のなかに定着した.

『建築講話』の訳出出版にいたるまでのラスキンおよびヴィオレ =ルニデュクに対するイメージの形成過程は，アメリカ国内の建 築・美術論壇の内部事情に左右され, きわめて地域性が高かった. 特に, ラスキンを明確に機能主義者と見做す潮流があったことと， ヴィオレ =ル＝デュクを強いて古典主義者と見做そうとしたことの 2 点は，ときの国内動向を反映した独自性をもつ。重要なのは，こ のように付託されたイメージの正誤ではない.アメリカの建築論壇 は，このイメージ形成を通じてこそ，混乱した様式論争の背後に一 貫して, 機能主義的建築理論に関する議論を継続してきたのである.

\section{参考文献}

1) Stein, R.: John Ruskin and the Aesthetic Thought in America, 1840-1900, Harvard University Press, 1967.

2) Hitchcock, H.-R.: Ruskin and American Architecture, Or Regeneration Long Delayed, Concerning Architecture, The Penguin Press, pp.166-208, 1968.

3) Brooks, M. W.: Ruskin's Influence in America, John Ruskin and Victorian Architecture, Rutgers University Press, pp.276-298, 1987.

4) Weingarden, L. S.: Louis H. Sullivan and a 19th-Century Poetics of Naturalized Architecture, Ashgate, 2009.

5) Reiff, D. D.: Viollet-le-Duc and American 19th Century Architecture, Journal of Architectural Education, Vol. 42, No.1, pp.32-47, 1988.

6) Middleton, R. and Watkin, D.: Neoclassical and 19th Century Architecture, Abrams, 1980.

7) Early, J.: Romanticism and American Architecture, A. S. Barnes and Co., 1965. 
注

注 1) Loran, E.: Introduction, Form and Function: Remarks on Art, Design, and Architecture, Small, H. A., ed., University of California Press, p.xiii, 1947. 以下, 書名, 記事名および本文の翻訳はすべて論者に よる。また，原文イタリックは翻訳では傍点とする。

注 2) "Baffling Phenomenon". Pevsner, N.: Some Architectural Writers of the Nineteenth Century, Clarendon Press, p.188, 1972.

注 3) Stein:1967, p.13.

注 4) Early:1965, pp.98-108; Stein:1967, pp.12-13; Brooks:1987, pp.279, 297.

注 5） Stein:1967, pp.203-205; Middleton and Watkin:1980, pp.359-380; Brooks:1987, pp.289-291; Weingarden: 2009, pp.188-212, 246-247.

注 6) Stein:1967, p.203; Brooks:1987, p.290. 引用はブルックスより.

注 7) A Graduate of Oxford: Modern Painters, Wiley \& Putnam, 1847. 原書は Smith, Elder \& Co. から 1843 年に発売.

注 8) Ruskin, J.: The Seven Lamps of Architecture, J. Wiley, 1849. アメ リカにおける『建築の七燈』書評は 10 を超えるが，その一部は Brownell, R. L., ed.: The Contemporary Reviews of John Ruskin's The Seven Lamps of Architecture, Pallas Athene, 2009 に収録されている. Stein:1967, pp.63-69 も参照のこと.

注 9) Emerson[, R. W.]: Nature, James Monroe and Company, 1836.

注 10) Downing, A. J.: Architecture of Country Houses, D. Appleton \& Company, p.23, 1851.

注 11）「物質は，微かにでも神の特性を暗示するように作られているため に，ほとんど神にも近しい，神が外界に造り給うた作品を見つめ考えると き，このことを理解する，否，感じることによって，深く身震いするほど の満足がえられる.」Ibid., p.9.

注 12) Wright, N.: Horatio Greenough: The First American Sculptor, University of Pennsylvania Press, p.273, 1963.

注 13) いずれも Form and Function 所収. Criticism In Search of Beauty, Form and Function, pp.97-111; Structure and Organization, ibid., pp.113-129; Relative and Independent Beauty, ibid., pp.69-86.

注 14) Emerson, R. W.: English Traits, Philips, Sampson, and Company, p.12, 1856 .

注 15) Greenough, H.: American Architecture, Form and Function, pp.51-68. 初出は The United States Magazine, and Democratic Review, Vol.13, No.62, pp.206-210, 1843.8. 没後 The Southern Literary Messenger, Vol.19, No.8, pp.513-517, 1853.8 および The Crayon, Vol.2, No.15, pp.224-226, 1855.10 に再掲された.

注 16） 20 世紀のグリーノウ再評価は V・W・ブルックスによる『ニューイ ングランドの開花』（1936）からエマーソンの再評価に付随して始まった が,このことは先行研究には示されていない. その歷史的経緯については 別稿にて論ずる

注 17) Metzger, C. R.: Emerson and Greenough: Transcendental Pioneers of an American Esthetic, University of California Press, p.100 1954.

注 18) Ibid.

注 19）『イギリスの特質』については注 14 参照. グリーノウ回想録は Greenough, H.: A Memorial of Horatio Greenough: Consisting of a Memoir, Selections from his Writings and Tributes to his Genius, Tuckerman, H. T., ed., G. P. Putnam \& Co., 1853.

注 20) Transactions of the Cosmopolitan Art Association, Cosmopolitan Art Journal, Vol.1 No.3, p.96, 1857.3.

注 21) Hart, J. C.: Unity in Architecture, The Crayon, Vol.6, No.3, p.85, 1859.3 .

注 22) Eidlitz, L.: On Style, The Crayon, Vol.5 , No.5 , pp.139-142, 1858.5

注 23) Viollet-le-Duc, E. E.: Entretiens sur l'architecture, tome premier, A. Morel et $\mathrm{C}^{\mathrm{ie}}, 1863$.

注 24） Reiff:1988, p.34 には 60 年代中葉以降の主要なヴィオレ＝ル＝デュ ク関連記事がまとめられているが，アメリカの同氏受容の開始はさらに 10 年早い. 50 年代に French, Putnam's Monthly Magazine of American Literature, Science, and Art, Vol.3, No.14, pp.227, 1854.2 等がある.

注 25) Wight, P. B.: Henry Van Brunt: Architect, Writer and Philosopher Part I, The Inland Architect and News Record, Vol.23, No.3, p.29, 1894.4
注 26) Viollet-le-Duc, E. E.: Discourses on Architecture, Brunt, H. V., trans., Grove Press, 1875.

注 27) Van Brunt, H.: Richard Morris Hunt, Architecture and Society: Selected Essays of Henry Van Brunt, Coles, W. A., ed., The Belknap Press of Harvard University Press, p.331, 1969.

注 28) A Great Imaginative Interpreter of Renaissance Traditions, The Architectural Record, Vol.35, No.5, p.465, 1914.5.

注 29) Van Brunt, H.: Cast Iron In Decorative Architecture, The Crayon, Vol.6, No.1, pp.15-20, 1859.1; Eidlitz, L.: Cast Iron And Architecture, The Crayon, Vol.6, No.1, pp.20-24, 1859.1.

注 30) Holliday, K. E.: Leopold Eidlitz: Architecture and Idealism in the Gilded Age, W. W. Norton \& Company, p.4, 2008.

注 31）これは当時の『建築の七登』と『ヴェネツィアの石』の版数の比較 によっても示される（Hitchcock:1968, pp.172-173）。また，アイドリッ ツはラスキンをむしろロマネスク愛好者と見做した (Eidlitz:1859, p.26).

注 32) Association for the Advancement of Truth in Art, The New Paths, Vol.1, No.1, p.12, 1863.5. 誌名はラスキンの The Two Paths より.

注 33) Schuyler, M.: The Work Of William Appleton Potter, The

Architectural Record, Vol.26, No.3, p.181, 1909.9.

注 34) Van Rensselaer, M. G.: Henry Hobson Richardson and His Works, Dover Publishing, p.15, 1969. 同書は公式の伝記で初版は 1888 年.なお, ヴィオレ =ル＝デュクに対する学生ボイコットの理由には現在, 様式論争 よりも人事権に関する政治的な理由が指摘される. Mallgrave, H. F.: Modern Architectural Theory: A Historical Survey, 1673-1968, Cambridge University Press, p.128, first paperback edition, 2009 参照. 注 35) Wight, P. B.: H. H. Richardson, Inland Architecture and News Record, Vol.7, No.7, p.60, 1886.5. ただし, リチャードソンの行動は『建 築講話』の発表後であるため, これはワイトの事実誤認である.

注 36) 『建築講話』海賊版は Viollet-le-Duc, [E. E.]: Entretiens sur l'architecture, Gregg Press, 1965 として出版された. ヴァン・ブラントが 『ザ・ネイション』（2巻第 $40 ， 41$ 号）に寄稿した書評は当時匿名だった が，その後論集に収録された（Van Brunt:1969, pp.89-96）

注 37) Wight, P. B.: The History of Art and Aesthetics from the Earliest Times to the Fall of the Roman Empire by Viollet-le-Duc, The Manufacturer and Builder, Vol.2, No.11, pp.323-326, 1870.11.1.

注 38) A Worse than Worthless Text-Book, The Nation, Vol.4, No.95, pp.332-333, 1867.4 .

注 39) Samson, G. W.: Elements of Art Criticism, J. B. Lippincott \& Co., 1867. 引用は 81 ページより

注 40） ただし当時はまだヴィオレ＝ル＝デュクの書目は英語で読むことが できず，翌月には他誌にこの点の指摘を含む反論記事が掲載された． E. B. Art Criticism, The Round Table, A Saturday Review of Politics, Finance, Literature, Society and Art, Vol.5, No.121, p.316, 1867.5.

注 41) Stillman, W. J.: Ruskin and his Writings, The Nation, Vol.7, No.178, p.437, 1868.11.6.

注 42) 特に Stillman, W. J.: John Ruskin, The Century Magazine, Vol.35, No.3, pp.357-366, 1888.1 を参照のこと.

注 43) Cook, C.: A Corner Stone, The Galaxy, Vol.5, No.2, pp.144-153, 1868.2 .

注 44） 翻訳版『建築講話』の書評 Viollet-le-Duc's Discourses, The American Architect and Building News, Vol.1, pp.115-117, 1876.4.8 も やはりヴィオレ＝ル＝デュクを古典主義者と見做している．なお，ヴィオ レ=ル＝デュクが（スタージス以外にも） ゴシック主義者と見做されはじ めるのは 1879 年の追悼記事. M. Viollet-le-Duc, The American Architect and Building News, Vol.6, pp.114-115, 1879.10 以降のこと.

注 45) Sturgis, R., Jr.: Modern Architecture, The North American Review, Vol.112, Nos.230, 231, pp.160-177, 370-391, 1871.1, 4.

注 46) Our Furniture: What It Is, and What It Should Be, The New Path, Vol.2, Nos.4, 5, pp.55-62, 65-72, 1865.4-5 および Viollet-le-Duc's French Mediaeval Architecture, The Nation, Vol.9, Nos.215, 217, pp.134-135, 173-174, 1869.8 等. 後者の同定は Reiff:1988, p.34 参照.

注 47） ラスキンの著作はアメリカでは早くから船舶美学の文脈でも読まれ ていた. On Boats, The Crayon, Vol.3, No.11, pp.332-335, 1856.11 は, ラスキン書目のなかでは今日比較的目立たない『イングランドの港』（The Harbours of England, E. Gambart and Co., 1856) の書評に 4 ページを費 やし, 船舶と生物の類推や, 船舶が神の被造物に比肩されることを語った。 


\section{RUSKIN AND VIOLLET-LE-DUC}

The genealogy of functionalist architectural theory in mid-19th century America

\section{Hiroshi EMOTO*}

* Doctoral Student, Dept. of Architecture, Graduate School of Engineering, The University of Tokyo, M.Eng.

The decade after the late 1840's in America saw a surge in popularity of the natural and artistic philosophy of John Ruskin [1819-1900], right after the domestic bootleg publication of his Modern Painters in 1847; this was due to the intellectuals' contemporary understanding of his theory as suitable for the domestic transcendentalist thought epitomized by Ralph Waldo Emerson [1803-82]. So huge was the impact of Ruskin's The Seven Lamps of Architecture in this context that, just after its publication in 1849, and together with Emerson's transcendental world view, it influenced the theory of beauty espoused by Andrew Jackson Downing [1815-52], an eminent architect and landscape designer.

Since Ruskin's theory was first understood as a rational principle of architecture by American readers, Emerson saw Ruskin's notion of architecture as being similar to that of his friend sculptor, Horatio Greenough [1805-52], who had formulated a pure functionalist theory throughout his prolific writings, although without much popularity, before his untimely death. Thus Emerson, in his English Traits in 1856 and in other occasions, traced Ruskin's functionalist-transcendentalist philosophy of architecture back to Greenough's writings. American architects in the 50's came to know Greenough's theory through Emerson's texts and their reading of Ruskin, in such a way that the functionalist line of thought was discussed referring mainly to Ruskin, without mentioning Greenough, for well over half a century from the mid-60's.

The late 50's were marked by the first public architectural debate in America, the topic of which was the legitimate use of iron as a decorative and structural material. Ruskin, the most trusted authority during the 50's, who in The Seven Lamps disavowed the use of cast iron in construction, began to be questioned on his rationality and the legitimacy of his dogma. Although the young Henry Van Brunt [1832-1903] and the mid-career Leopold Eidlitz [1823-1908] were apparently at odds over their belief and disbelief in Ruskin's gospel, they had in fact reached a consensus on their prospects for iron's promising future.

The reception of the architectural theory of Eugène Emmanuel Viollet-le-Duc [1814-79] by American architects would start soon after, through Van Brunt's review of Entretiens sur l'architecture (1863), titled "Architectural Reform" (1866), which took place just a few years after Viollet-le-Duc's controversial appointment as a lecturer at the École des Beaux-Arts. This short time frame for the American introduction of Entretiens had an important motive; namely, that of shifting the functionalist discussion of architecture from Ruskin towards Viollet-le-Duc, at least within the so-called "French school". The all-too-frequent cross-references to these theoreticians in articles touching Viollet-le-Duc after the publishing of Van Brunt's article bear proof to it.

Another motive was the gradual perception and dismissal of Ruskin as a non-generalist from the early 60's, under the wave of Gothic revival in America, inspired by its English counterpart. Viollet-le-Duc became thus Ruskin's substitute in the search for universal truth in architecture. But just as Ruskin in America was not truly a Gothicist in the 50's, nor was Viollet-le-Duc there from the 60's onward; and the latter would rather be interpreted as a champion of the Beaux-Arts ideal of Classic architecture.

As American commitment to French culture blossomed, Ruskin began to be severely criticized. The articles on Ruskin from just after the Paris Exhibition in 1867 stand as the first complete denial of his theory. Despite this negative tide, the American architect and art critic Russell Sturgis [1836-1909] did posit a pure functionalist theory of architecture in his work "Modern Architecture" (1871), in which Greenough's theory was revivified without giving him due credit, and by falsely quoting Ruskin's words, portraying him as both functionalist and transcendentalist. 